Article

\title{
Functional Characterization of RNA Silencing Suppressor P0 from Pea Mild Chlorosis Virus
}

\author{
Qian Sun ${ }^{1,2}$, Tao Zhuo ${ }^{2}$, Tianyu Zhao ${ }^{2}$, Cuiji Zhou ${ }^{2}$, Yuanyuan $\mathrm{Li}^{2}$, Ying Wang ${ }^{2}{ }^{\mathbb{D}}$, \\ Dawei $\mathrm{Li}^{2}{ }^{2}$, Jialin $\mathrm{Yu}^{2}$ and Chenggui Han ${ }^{2, *} \mathbb{C}$ \\ 1 College of Plant Protection, Shenyang Agricultural University, Shenyang 110866, China; \\ sunqian5328@syau.edu.cn \\ 2 State Key Laboratory for Agro-Biotechnology and Ministry of Agriculture Key Laboratory of Pest \\ Monitoring and Green Management, College of Plant Protection, China Agricultural University, \\ Beijing 100193, China; zhuotaotao@gmail.com (T.Z.); zhaotianyu@alu.cau.edu.cn (T.Z.); \\ zhoucuiji@fosu.edu.cn (C.Z.); hunan_lyy@cau.edu.cn (Y.L.); yingwang@cau.edu.cn (Y.W.); \\ Dawei.Li@cau.edu.cn (D.L.); yjl@cau.edu.cn (J.Y.) \\ * Correspondence: hanchenggui@cau.edu.cn
}

Received: 1 September 2020; Accepted: 23 September 2020; Published: 27 September 2020

\begin{abstract}
To counteract host antiviral RNA silencing, plant viruses encode numerous viral suppressors of RNA silencing (VSRs). P0 proteins have been identified as VSRs in many poleroviruses. However, their suppressor function has not been fully characterized. Here, we investigated the function of P0 from pea mild chlorosis virus (PMCV) in the suppression of local and systemic RNA silencing via green fluorescent protein (GFP) co-infiltration assays in wild-type and GFP-transgenic Nicotiana benthamiana (line 16c). Amino acid deletion analysis showed that N-terminal residues Asn 2 and Val 3, but not the C-terminus residues from 230-270 aa, were necessary for PMCV P0 ( $\left.\mathrm{P0}{ }^{\mathrm{PM}}\right)$ VSR activity. $\mathrm{P0}^{\mathrm{PM}}$ acted as an F-box protein, and triple LPP mutation (62LPxx79P) at the F-box-like motif abolished its VSR activity. In addition, $\mathrm{PO}^{\mathrm{PM}}$ failed to interact with S-phase kinase-associated protein 1 (SKP1), which was consistent with previous findings of $\mathrm{P} 0$ from potato leafroll virus. These data further support the notion that VSR activity of P0 is independent of P0-SKP1 interaction. Furthermore, we examined the effect of $\mathrm{P} 0^{\mathrm{PM}}$ on ARGONAUTE1 (AGO1) protein stability, and co-expression analysis showed that $\mathrm{P}^{\mathrm{PM}}$ triggered AGO1 degradation. Taken together, our findings suggest that $\mathrm{P}^{\mathrm{PM}}$ promotes degradation of AGO1 to suppress RNA silencing independent of SKP1 interaction.
\end{abstract}

Keywords: PMCV; VSR; F-box protein; SKP1; AGO1

\section{Introduction}

RNA silencing is an antiviral immune mechanism in a variety of eukaryotes including fungi, plants, and invertebrates. Antiviral RNA silencing is initiated when virus double-stranded RNA (dsRNA) structures are recognized and are processed into virus-derived small interfering RNAs (vsiRNAs) by RNaseIII-like enzymes Dicer-like proteins (DCLs) [1,2]. Then, vsiRNAs are loaded into ARGONAUTE (AGO)-containing protein complexes called RNA-induced silencing complexes (RISCs) to target viral RNAs for degradation [3-7]. Fragments generated by RISC cleavage are converted into dsRNA by RNA-dependent RNA polymerases (RDRs) and its cofactor SUPPRESSOR OF GENE SILENCING 3 (SGS3) encoded by the plant host to produce secondary vsiRNAs [8-11]. RDR1, RDR2, and RDR6 are important factors in vsiRNA production during viral infections [10,12-14].

To counteract host antiviral RNA silencing, plant viruses have evolved numerous viral suppressors of RNA silencing (VSRs). Although VSRs have been identified in almost all plant virus genera, there is clear diversity in VSR sequence and structure, indicating that they have evolved independently [15]. 
Recent data have shown that VSRs use various strategies to interfere with different phases of the silencing pathway including initiation of RNA silencing, dicing of viral dsRNA, assembly of RISCs, and amplification by RDRs [16-19]. A common strategy used by VSRs is to bind dsRNA or siRNA. The turnip crinkle virus (TCV) P38 protein and cucumber mosaic virus (CMV) 2b protein have been found to bind long dsRNA and block vsiRNA biogenesis [2,20,21]. Moreover, tomato bushy stunt virus (TBSV) P19 protein specifically binds to siRNA to prevent siRNA-AGO complex formation [22-24]. Several studies have shown that VSRs directly interact with RNA silencing components. V2 from tomato yellow leaf curl virus (TYLCV) inhibits RDR6-mediated amplification by directly interacting with SGS3 [25] and P6 from cauliflower mosaic virus (CaMV), which effectively suppresses silencing by interacting with dsRNA-binding protein 4 (DRB4) [26]. CMV 2b is the first to be identified to interact with AGO1, which inhibits the cleavage activity of AGO1 [27]. TCV P38 directly interacts with and suppresses AGO proteins by mimicking the endogenous GW/WG repetitive motif [28]. In addition, some VSRs have been shown to mediate the degradation of AGO proteins. For example, P25 from potato virus $X(\mathrm{PVX})$ interacts with AGO1, AGO2, AGO3, and AGO4 and selectively promotes degradation of AGO1 in a proteasome-dependent manner [29]. Similarly, CP from tomato ringspot virus (TRSV) binds to and enhances AGO1 degradation through autophagy [30]. P0 proteins, the VSRs of poleroviruses, have also been shown to trigger the degradation of AGO1 via autophagy [31-35].

The poleroviruses are distributed worldwide, infecting many crops of economic importance and causing severe plant diseases and yield losses. As previously reported, P0 proteins of several poleroviruses suppress RNA silencing [33,35-47]. Although P0 proteins have a very low amino acid sequence identity, they have a conserved F-box-like motif $\left[\operatorname{LPxx}(\mathrm{L} / \mathrm{I}) \mathrm{x}_{10-13} \mathrm{P}\right]$ in the N-terminal region and conserved residues $\left[(\mathrm{K} / \mathrm{R}) \mathrm{IYGEDGX}_{3} \mathrm{FWR}\right]$ in the $\mathrm{C}$-terminal region $[35,40]$. Silencing suppression activity assays indicated that some residues in F-box-like and FWR motifs are important for P0 suppressor activity $[32,35,39,40,42-44,48]$. Other studies have shown that P0 proteins interact via the F-box motif with S-phase kinase-associated protein 1 (SKP1), which belongs to the SKP1-Cullin 1-F-box (SCF) E3 ubiquitin ligase family $[35,43,49]$. However, AGO1 degradation triggered by P0 is sensitive to autophagy inhibitors rather than proteasome inhibitors [32,34].

In previous research, we identified a tentative novel virus, pea mild chlorosis virus (PMCV), infecting field peas and faba beans in China [50]. PMCV has a genomic organization that is typical of poleroviruses, and the open reading frame ORF0 (nt 51-863) encodes the P0 protein $\left(\mathrm{P0} 0^{\mathrm{PM}}\right)$ [50]. However, whether $\mathrm{PO}^{\mathrm{PM}}$ protein is a VSR remains unclear. In this study, we investigated the ability of $\mathrm{P}^{\mathrm{PM}}$ to suppress local and systemic RNA silencing, trigger AGO1 degradation, and interact with SKP1. In addition, we also identified the critical amino acids responsible for $\mathrm{P}^{\mathrm{PM}}$ VSR activity.

\section{Results}

\section{1. $P 0^{P M}$ Suppressed Local but Not Systemic RNA Silencing}

To test whether $\mathrm{PO}^{\mathrm{PM}}$ is an RNA silencing suppressor, a green fluorescent protein (GFP) agroinfiltration assay was performed in Nicotiana benthamiana [51,52]. Agrobacterium tumefaciens harboring the binary vector PGDG that expressed GFP [53] was mixed with $A$. tumefaciens containing binary constructs coding for $\mathrm{P0} 0^{\mathrm{PM}}$, potato leafroll virus (PLRV) $\mathrm{P0}\left(\mathrm{P0}^{\mathrm{PL}}\right)$, TBSV P19 $\left(\mathrm{P}^{\mathrm{TBSV}}\right)$, or empty binary vector $\mathrm{pGD}$ as described in the methods. The empty vector $\mathrm{pGD}$ served as a negative control, and $\mathrm{P} 0^{\mathrm{PL}}$ and $\mathrm{P} 19^{\mathrm{TBSV}}$ were used as positive controls $[43,54]$. All the mixtures were transiently co-infiltrated into $N$. benthamiana leaves. Leaf patches infiltrated with GFP/pGD showed negligible GFP fluorescence under long-wavelength UV light at 5 days post-infiltration (dpi), which indicated effective induction of GFP RNA silencing (Figure 1A). In contrast, leaf patches infiltrated with GFP/P0 ${ }^{\mathrm{PM}}$ revealed strong GFP fluorescence similar to GFP $/ \mathrm{P}^{\mathrm{PL}}$ and GFP/P19 $9^{\mathrm{TBSV}}$. To confirm these observations, the GFP protein level was measured by Western blot, and we found that GFP protein levels were consistent with the results described above and were rarely detected in the leaf patches infiltrated with $\mathrm{GFP} / \mathrm{pGD}$, while GFP/P0 ${ }^{\mathrm{PM}}$-infiltrated leaf patches showed high accumulation of GFP similar to the 
$\mathrm{GFP} / \mathrm{P0} 0^{\mathrm{PL}}$ and GFP/P19 ${ }^{\mathrm{TBSV}}$ positive controls (Figure $1 \mathrm{~B}$ ). These results indicate that $\mathrm{P}^{\mathrm{PM}}$ was able to suppress local GFP RNA silencing.
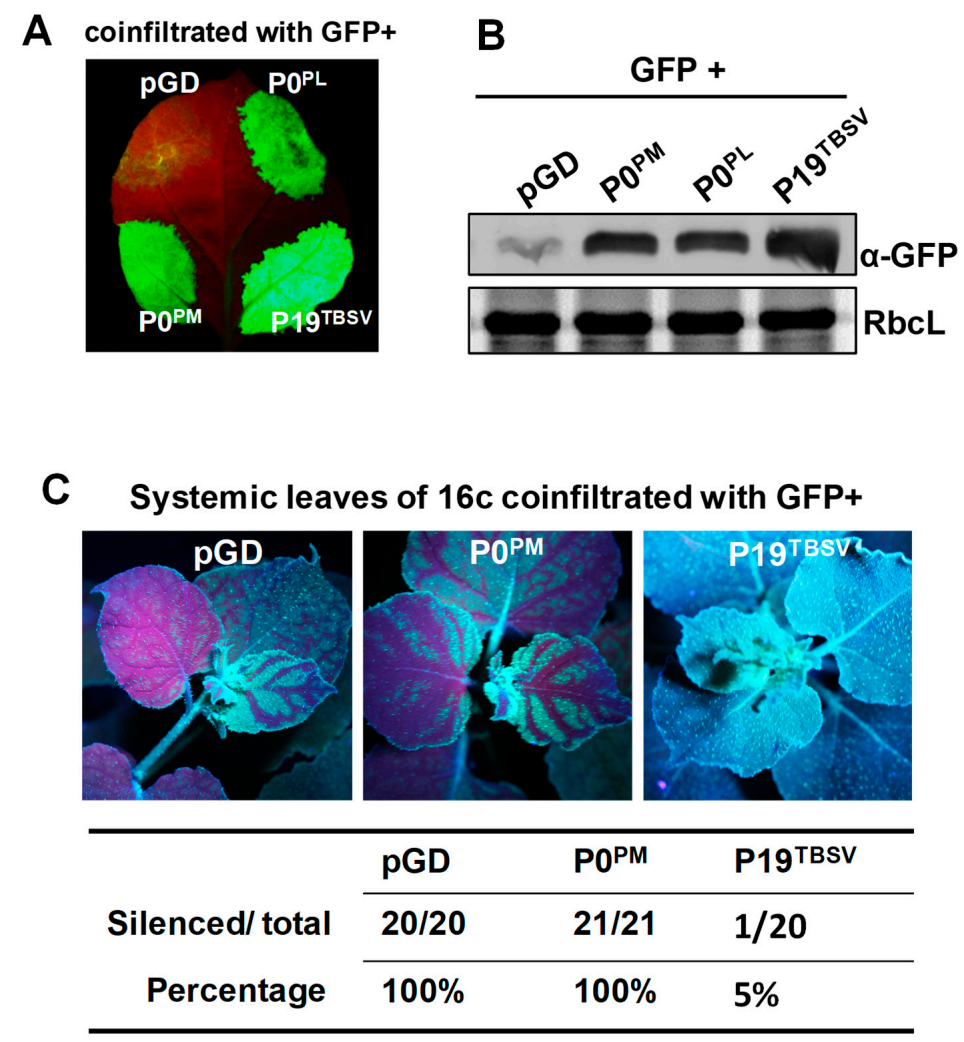

Figure 1. $\mathrm{P} 0{ }^{\mathrm{PM}}$ protein suppressed local but not systemic RNA silencing. (A) Agroinfiltration of $N$. benthamiana leaves with green fluorescent protein (GFP) plus empty vector $\mathrm{pGD}, \mathrm{P} 0^{\mathrm{PL}}, \mathrm{P} 19^{\mathrm{TBSV}}$, or $\mathrm{P} 0{ }^{\mathrm{PM}}$. The empty vector pGD was used as negative control. $\mathrm{P} 0^{\mathrm{PL}}$ and $\mathrm{P} 19^{\mathrm{TBSV}}$ were used as positive controls. Photographs were taken under long-wavelength UV light at 5 days post-infiltration (dpi). (B) GFP proteins from infiltrated leaf patches were detected by Western blotting. GFP was detected with GFP polyclonal antiserum. RbcL is the Rubisco large subunit. (C) Systemic RNA silencing suppression activity of $\mathrm{P} 0 \mathrm{PM}$. GFP was transiently co-expressed in leaves of GFP transgenic $N$. benthamiana $16 \mathrm{c}$ plants with $\mathrm{pGD}, \mathrm{P} 0^{\mathrm{PM}}$, or $\mathrm{P} 19^{\mathrm{TBSV}}$. The empty vector $\mathrm{pGD}$ and $\mathrm{P} 19^{\mathrm{TBSV}}$ were used as negative and positive controls, respectively. Photographs of the upper leaves were taken under long-wavelength UV light at $14 \mathrm{dpi}$. The ratios below the images show the number of systemic silencing plants out of the total number of infiltrated plants. The systemic silencing efficiency was scored in three independent experiments.

We conducted GFP agroinfiltration assays in N. benthamiana 16c [52] to analyze whether $\mathrm{P}^{\mathrm{PM}}$ suppresses the long-distance spread of the systemic silencing signal. At $14 \mathrm{dpi}$, GFP fluorescence signals were observed in the upper leaves under long-wavelength UV light, and the percentage of systemic silencing suppression was calculated (Figure 1C). All plants infiltrated with GFP/pGD or $\mathrm{GFP} / \mathrm{P0}{ }^{\mathrm{PM}}$ exhibited systemic RNA silencing. In contrast, systemic RNA silencing was suppressed in plants infiltrated with GFP/P19 $19^{\mathrm{TBSV}}$ with only $5 \%$ exhibiting systemic RNA silencing (Figure 1C). These results indicate that $\mathrm{P} 0{ }^{\mathrm{PM}}$ did not suppress systemic RNA silencing.

\subsection{Requirement of $\mathrm{N}$ - and $\mathrm{C}$-Terminal Amino Acids of $P 0^{P M}$ for Suppressor Activity}

According to the previous studies, the $\mathrm{N}$ - and $\mathrm{C}$-terminal amino acids are critical for silencing the suppressor activity of P0 $[39,46]$. To verify whether the $\mathrm{N}$ - and C-terminal amino acids are required for $\mathrm{P} 0{ }^{\mathrm{PM}}$ VSR activity, $\mathrm{N}$-terminal deletion mutants $\Delta 2$ and $\Delta 3$ representing a single amino acid deletion at position 2 or 3, respectively, and C-terminal truncation mutants $\Delta 229-270$ and $\Delta 230-270$ representing 
deletion of 42 or 41 amino acids in the C-terminus, respectively, were constructed as described in the methods (Figure 2A). Then, wild-type N. benthamiana were co-infiltrated with $A$. tumefaciens carrying pGDG and $A$. tumefaciens carrying these four $\mathrm{P} 0^{\mathrm{PM}}$ mutants, wild-type $\mathrm{P} 0^{\mathrm{PM}}$, or empty binary vector pGD. At 5 dpi, GFP fluorescence in leaves co-infiltrated with GFP and $\Delta 2, \Delta 3$, or $\Delta 229-270$ was not detected as in leaves co-infiltrated with GFP/pGD (Figure 2B). Interestingly, the leaves co-infiltrated with GFP/ $\triangle 230-270$ showed a high level of GFP fluorescence similar to GFP/P0 ${ }^{\mathrm{PM}}$ (Fig. 2B). Western blot analyses showed that GFP protein accumulation was consistent with GFP fluorescence levels (Figure 2C). These results indicate that the $\mathrm{N}$-terminal residues Asn 2 and $\mathrm{Val} 3$ of $\mathrm{P} 0^{\mathrm{PM}}$ were necessary for RNA silencing suppression function, whereas C-terminal 41 residues (230-270 aa) were not required.

A

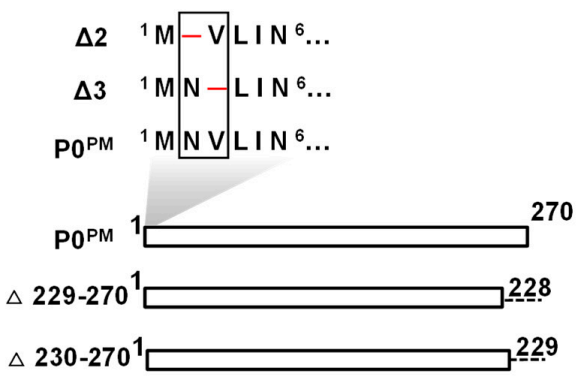

B

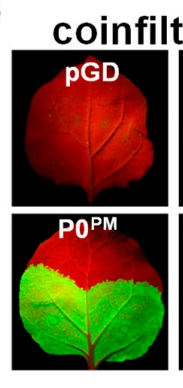

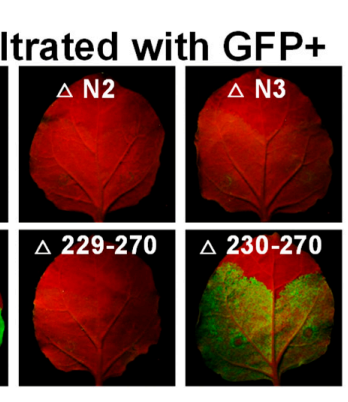

C

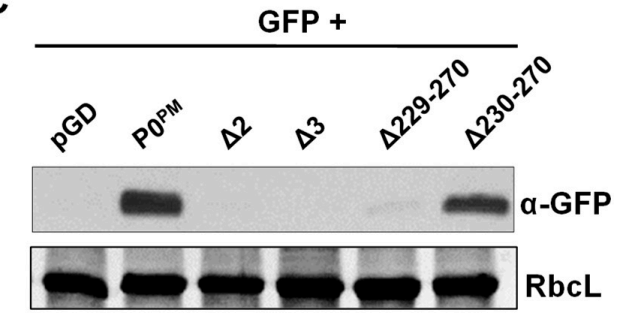

Figure 2. Requirement of $\mathrm{N}$ - and C-terminal amino acids of $\mathrm{P} 0^{\mathrm{PM}}$ for suppressor activity. (A) Schematic representation of amino acids deleted (-) in the $\mathrm{N}$-terminus of $\mathrm{P} 0^{\mathrm{PM}}$ (upper panel) and C-terminal truncation mutants (lower panel). Numbers correspond to the amino acid positions within the $\mathrm{P} 0^{\mathrm{PM}}$ sequence. (B) Agroinfiltration of $N$. benthamiana leaves with GFP plus empty vector $\mathrm{pGD}, \mathrm{P} 0^{\mathrm{PM}}$ mutants or $\mathrm{P} 0^{\mathrm{PM}}$, respectively. The empty vector $\mathrm{pGD}$ was used as negative control. Photographs were taken under long-wavelength UV light at $5 \mathrm{dpi}$. (C) GFP proteins from infiltrated leaves were detected by Western blotting at $5 \mathrm{dpi}$. GFP was detected with GFP polyclonal antiserum. RbcL is the Rubisco large subunit.

\subsection{Critical Residues in $P 0^{P M}$ Motifs Were Required for Suppressor Activity}

The above results showed that $\mathrm{PO}^{\mathrm{PM}}$ is an RNA silencing suppressor; thus, we determined whether it also functions as an F-box-like protein. Multiple alignment of the P0 amino acid sequences from 10 poleroviruses revealed that $\mathrm{P}^{\mathrm{PM}}$ had a similar sequence (LPFLFGGFEFLNGQLVIP) to the F-box-like motif [LPxx(L/I) $\left.\mathrm{X}_{10-13} \mathrm{P}\right]$ from residues 62 to 79 (Figure 3A). Interestingly, residue 66 at the $\mathrm{L} / \mathrm{I}$ position was an $\mathrm{F}$ instead of the consensus $\mathrm{L}$ or I residue. To determine whether the similar F-box-like motif in $\mathrm{P}^{\mathrm{PM}}$ is functional for $\mathrm{P}^{\mathrm{PM}}$ VSR activity, a series of $\mathrm{P} 0^{\mathrm{PM}}$ mutants in the F-box-like motif was constructed including LP (amino acids 62 and 63 from LP to AA) and LPP (amino acids 62,63 , and 79 from LPP to AAA). Then, LP or LPP mutants were transiently co-infiltrated with GFP in $N$. benthamiana. At $5 \mathrm{dpi}$, GFP fluorescence showed that the LP mutant did not affect its VSR activity; however, the LPP mutant abolished its VSR activity (Figure 3C). These results were consistent with a previous observation for enamovirus pea enation mosaic virus-1 $\mathrm{P} 0$, where substitution of the conserved LP residues did not affect the suppressor activity while substitution of the conserved 
LPP residues inhibited its suppressor activity [55]. Western blot analyses showed that GFP protein accumulation was consistent with fluorescence levels (Figure 3D). These results demonstrate that the similar F-box-like domain was essential for $\mathrm{P0}^{\mathrm{PM}}$ suppressor function.

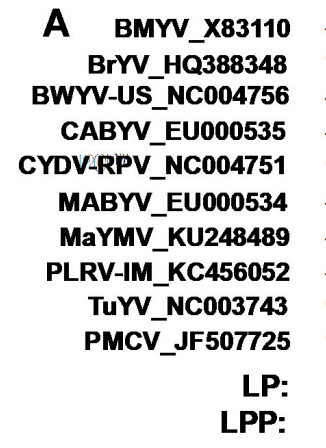
B BMYV $X 83110$ BrYV_HQ388348

C

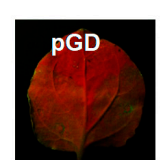

coinfiltrated with GFP+

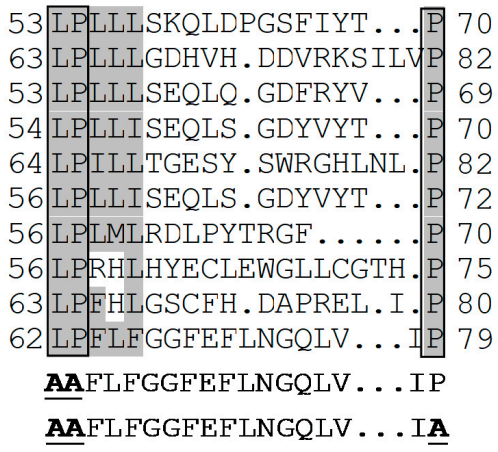

199 HLFGEARGMDEWRLAN 214

209 KIYGEDGEISEWRIAN 224

198 RIYGEDSGLDEWRLAN 213

199 RIYGEDGGIDEWRLAN 214

220 EIVVEGVPVAFWDAAG 235

201 RIYGEDGGIDEWRIAN 216

223 NALGPAGHKDEWRIAG 238

190 QILIQGRAKSERAITG 205

209 KIYGEDGE ISEWRIAN 224

215 RCYGKALTSDIWEIFG 230

RCYGKALTSDRWELFG

RCYGKALTSDIRELFG

RCYGKALTSDRRELFG

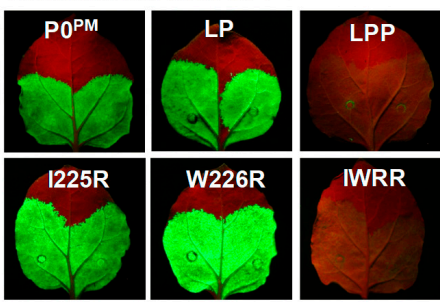

D

GFP +

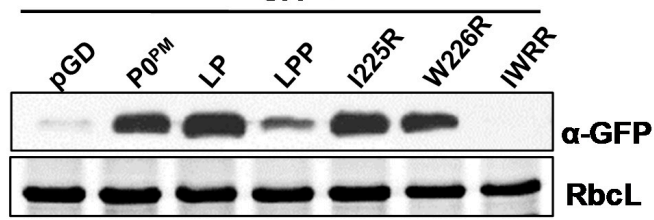

Figure 3. The critical residues in $\mathrm{P}^{\mathrm{PM}}$ motifs were required for its suppressor activity. (A) Multiple alignment of the F-box-like domains of $\mathrm{P} 0$ amino acid sequences from 10 poleroviruses. The region (amino acids 62 to 79 ) in $\mathrm{P}^{\mathrm{PM}}$ has homology to F-box-like domains. The LP mutant of $\mathrm{P}^{\mathrm{PM}}$ indicates a double mutation at amino acids 62 and 63 from LP to AA. The LPP mutant of $\mathrm{P} 0{ }^{\mathrm{PM}}$ indicates a triple mutation at amino acids 62, 63, and 79 from LPP to AAA. (B) Multiple alignment of the FWR motif of P0 amino acid sequences from 10 poleroviruses. I225R mutant of $\mathrm{P} 0{ }^{\mathrm{PM}}$ indicates the point mutation at amino acid 225 from I to R. W226R mutant of $\mathrm{P} 0{ }^{\mathrm{PM}}$ indicates the point mutation at amino acid 226 from $\mathrm{W}$ to $\mathrm{R}$. The IWRR mutant of $\mathrm{P} 0{ }^{\mathrm{PM}}$ indicates a double mutation at amino acids 225 and 226 from IW to RR. (C) Agroinfiltration of $N$. benthamiana leaves with GFP plus empty vector $\mathrm{PGD}, \mathrm{LP}, \mathrm{LPP}, \mathrm{I} 225 \mathrm{R}, \mathrm{W} 226 \mathrm{R}, \mathrm{IWRR}$, or P0 ${ }^{\mathrm{PM}}$. The empty vector $\mathrm{pGD}$ was used as negative control. Photographs were taken under long-wavelength UV light at 5 dpi. (D) GFP proteins from infiltrated leaf patches were detected by Western blotting at $5 \mathrm{dpi}$. GFP was detected with GFP polyclonal antiserum. RbcL is the Rubisco large subunit. 
Most $\mathrm{P} 0$ proteins have a conserved C-terminal-proximal sequence (K/R) IYGEDGX ${ }_{3} \mathrm{FWR}$, and it has been demonstrated that the residues present in (K/R) IYGEDGX ${ }_{3} F W R$ affect P0 silencing suppressor activity $[40,43,46]$. Although the C-terminal-proximal sequence (두GKALTSDIWE) of $\mathrm{P} 0{ }^{\mathrm{PM}}$ displayed only $40 \%$ identity with the consensus sequence (Figure $3 \mathrm{~B}$ ), we found that the $\mathrm{P} 0^{\mathrm{PM}}$ mutant IWRR (amino acids 225 and 226 from IW to RR) destroyed $\mathrm{P}^{\mathrm{PM}}$ VSR activity. Mutation of amino acid 225 or 226 (I225 and W226, respectively) alone also suppressed RNA silencing (Figure 3C). Western blot analyses showed that GFP protein accumulation was consistent with GFP fluorescence levels (Figure 3D). These results indicate that I225/W226 residues were essential for $\mathrm{P}^{\mathrm{PM}}$ suppressor activity.

\section{4. $P 0^{P M}$ Failed to Interact with SKP1 in Yeast}

Previous studies have shown that polerovirus P0 proteins interact via the F-box-like motif with SKP1, which is a core component of SCF E3 ubiquitin ligase complex [35,46,49]. However, not all F-box $\mathrm{P} 0$ proteins interact with $\mathrm{SKP} 1$ such as $\mathrm{P} 00^{\mathrm{PL}-\mathrm{IM}}$ [43]. As shown above, $\mathrm{P0}{ }^{\mathrm{PM}}$ has a similar F-box like motif; therefore, we examined the interaction between $\mathrm{PO}^{\mathrm{PM}}$ and $\mathrm{SKP} 1$ using a yeast two-hybrid $(\mathrm{Y} 2 \mathrm{H})$ system. The ORFs of $\mathrm{P}^{\mathrm{PM}}$ and $\mathrm{N}$. benthamiana SKP1 (NbSKP1) were cloned into the GAL4 DNA binding domain (BD) and GAL4 activation domain (AD), respectively. The interaction of P0 from brassica yellows virus $\mathrm{P0}\left(\mathrm{P} 0^{\mathrm{Br}}\right)$ and $\mathrm{NbSKP} 1$ was used as a positive control [46]. Different combinations were mixed for mating, and the mixed transformants were transferred to synthetic dropout (SD) media lacking leucine and tryptophan (SD/-Leu/-Trp) and SD media lacking leucine, tryptophan, adenine, and histidine (SD/-Leu/-Trp/-Ade/-His) plates for 3-5 days. All mixed transformants were able to grow on $\mathrm{SD} /-\mathrm{Leu} /-\mathrm{Tr}$ plates; however, only yeast transformed with $\mathrm{BD}-\mathrm{P0} 0^{\mathrm{Br}}$ and $\mathrm{AD}-\mathrm{NbSKP} 1$ grew on SD/-Leu/-Trp/-Ade/-His plates (Figure 4). Thus, $\mathrm{P0}^{\mathrm{PM}}$ did not interact with NbSKP1 in yeast.

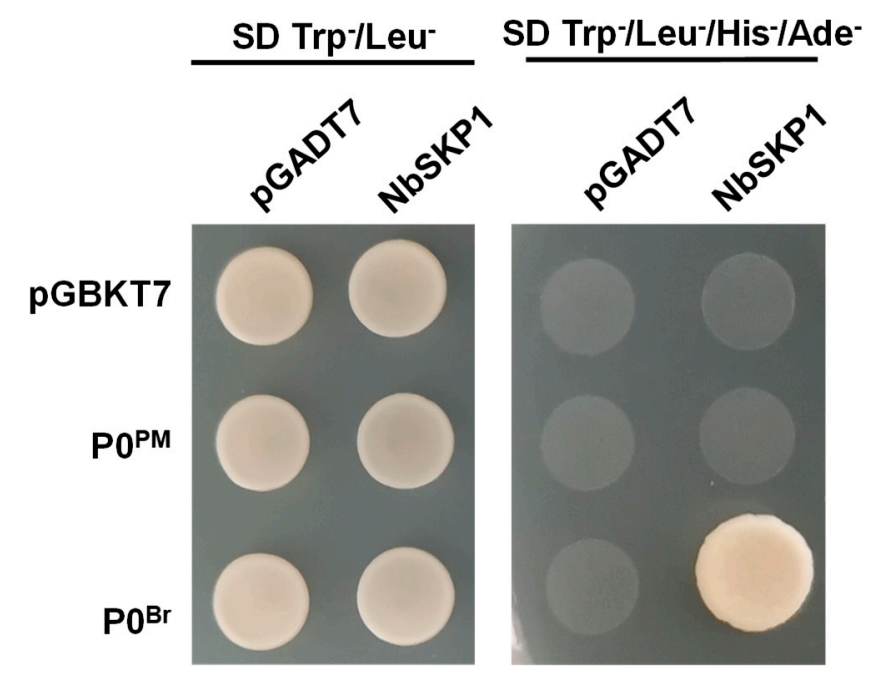

Figure 4. $\mathrm{P}^{\mathrm{PM}}$ protein failed to interact with $\mathrm{NbSKP} 1$. Analysis of interactions between $\mathrm{P} 0^{\mathrm{PM}}$ and NbSKP1 using the yeast two-hybrid system. $\mathrm{P}^{\mathrm{PM}}$ and $\mathrm{P}^{\mathrm{Br}}$ were cloned into bait vector pGBKT7 and transformed into yeast Y187, respectively. NbSKP1 was cloned into prey vector pGADT7 and transformed into yeast $\mathrm{AH} 109$. The interaction of $\mathrm{P0} 0^{\mathrm{Br}}$ and $\mathrm{NbSKP1}$ was used as a positive control. Yeast strains were grown on SD/-Leu/-Trp and SD/-Ade/-His/-Leu/-Trp and maintained at $30{ }^{\circ} \mathrm{C}$ for 3-5 days.

\subsection{AGO1 Protein Destabilization Triggered by $P 0^{P M}$ Was Correlated with Suppressor Activity}

Previous studies showed that poleroviruses' P0s target AGO1 protein for degradation [31,32,43,46]. Therefore, we investigated whether $\mathrm{P} 0{ }^{\mathrm{PM}}$ could also degrade AGO1 protein. To determine the effect of $\mathrm{P}^{\mathrm{PM}}$ on $\mathrm{AGO} 1$ protein stability, we performed an agroinfiltration assay. The $6 \times \mathrm{Myc}$-tagged Arobidopsis AGO1 (6Myc-AtAGO1) was transiently co-expressed with $3 \times$ Flag-tagged $\mathrm{P0}^{\mathrm{PM}}$ or $\mathrm{P0}^{\mathrm{PL}}$ in $N$. 
benthamiana leaves through agroinfiltration. $\mathrm{P}^{\mathrm{PL}}$-induced AtAGO1 degradation was used as a positive control [43]. P19 ${ }^{\mathrm{TBSV}}$ was added in this assay to ensure expression of $6 \mathrm{Myc}-\mathrm{AtAGO}$, and protein samples were analyzed at 5 dpi. As shown in Figure 5, the level of 6Myc-AtAGO1 was significantly reduced in the presence of $\mathrm{P} 0{ }^{\mathrm{PL}}$ compared with the empty vector pGD. When 6Myc-AtAGO1 was co-expressed with $\mathrm{P} 0{ }^{\mathrm{PM}}, 6 \mathrm{Myc}-\mathrm{AtAGO} 1$ protein was hardly detected, indicating that $\mathrm{P}^{\mathrm{PM}}$ triggered AGO1 degradation.

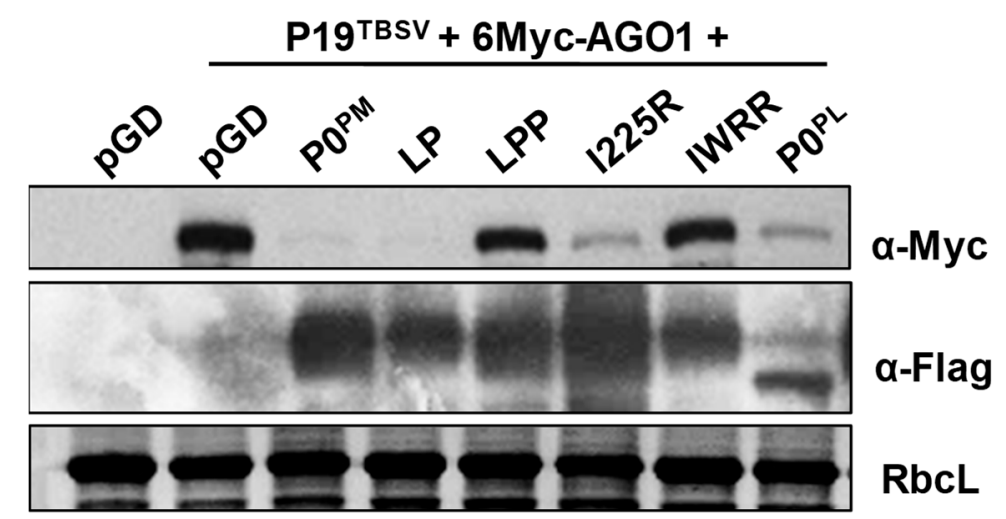

Figure 5. Effect of $\mathrm{P} 0^{\mathrm{PM}}$ and its mutants on the accumulation of AGO1 protein. The 6Myc-tagged AtAGO1 was transiently co-expressed with 3Flag-tagged $\mathrm{P} 0{ }^{\mathrm{PM}}$ and its mutants in $\mathrm{N}$. benthamiana leaves through agroinfiltration in the presence of $\mathrm{P} 19^{\mathrm{TBSV}}$. Protein samples were prepared from plant leaves at $5 \mathrm{dpi}$. The accumulation of AtAGO1 and $\mathrm{P} 0^{\mathrm{PM}}$ and its mutants was detected by Western blotting. AtAGO1 was detected with c-Myc monoclonal antibody; $\mathrm{PO} 0^{\mathrm{PM}}$ and its mutants were detected with Flag monoclonal antibody. RbcL is the Rubisco large subunit.

To further test whether AGO1 degradation is correlated with $\mathrm{P} 0{ }^{\mathrm{PM}}$ VSR activity, the $\mathrm{P} 0{ }^{\mathrm{PM}}$ mutants LP, LPP, I225R, and IWRR were transiently co-expressed with 6Myc- AtAGO1. Western blot analysis of 6Myc-AtAGO1 protein revealed that LP and I225R with VSR activity were able to trigger AGO1 degradation, whereas LPP and IWRR, without VSR activity, did not affect AGO1 accumulation, which was similar to the empty vector pGD (Figure 5). Taken together, these results suggest that $\mathrm{P} 0^{\mathrm{PM}}$ suppressor activity was correlated with AGO1 degradation.

\section{Discussion}

In this study, we investigated the function of the P0 protein encoded by the first ORF of PMCV. Like previously studied polerovirus $\mathrm{P} 0$ proteins, $\mathrm{P} 0^{\mathrm{PM}}$ is an RNA silencing suppressor with various levels of activity [33,35-46]. At present, P0 proteins from potato leafroll virus (PLRV), turnip yellows virus (TuYV, synonyms beet western yellows virus FL strain, BWYV-FL), beet mild yellowing virus (BMYV), cucurbit aphid-borne yellows virus (CABYV), cotton leafroll dwarf virus (CLRDV), melon aphid-borne yellow virus (MABYV), maize yellow dwarf virus-RMV2 (MYDV-RMV2), brassica yellows virus (BrYV), sugarcane yellow leaf virus (ScYLV), maize yellow mosaic virus (MaYMV), and cereal yellow dwarf virus (CYDV) suppress local RNA silencing [36,39-47,49,55]. Among them, the P0 proteins of PLRV, CYDV, ScYLV, MaYMV, BrYV, and MYDV-RMV2 also suppress systemic RNA silencing, in contrast to the P0 proteins of CLRDV, TuYV, and CABYV. Whether systemic suppression is induced by the P0 proteins of MABYV and BMYV is not reported [40,41]. In addition, the P0 proteins from TuYV, ScYLV, PLRV, BrYV, CABYV, and CYDV trigger cell death within the infiltration patch in Nicotiana species $[33,39,48,56]$, and the P0 proteins of ScYLV and TuYV trigger dose-dependent cell death in infiltrated $N$. benthamiana leaves. Recent studies show that $\mathrm{P} 0^{\mathrm{Tu}}, \mathrm{P} 0^{\mathrm{PL}}$, and $\mathrm{P}^{\mathrm{CA}}$ elicit a hypersensitive response in $N$. glutinosa, and $\mathrm{P} 0^{\mathrm{Tu}}$ is recognized by a resistance gene. In our study, we found that $\mathrm{P} 0{ }^{\mathrm{PM}}$ suppressed local RNA silencing but not systemic RNA silencing in an A. tumefaciens-mediated co-infiltration assay in wild-type and GFP-transgenic N. benthamiana. However, we did not observe any 
occurrences of cell death in the $\mathrm{P}^{\mathrm{PM}}$-inoculated $N$. benthamiana leaves. The reason for the differences in local and systemic RNA silencing suppression activity and hypersensitive responses between these P0s remains unclear.

Recently, we demonstrated that BrYV-A P0 $\left(\mathrm{PO}^{\mathrm{BrA}}\right)$ is a VSR that suppresses both local and systemic RNA silencing [46]. Deletion of a single amino acid at position 2 or 3 in the $\mathrm{N}$-terminus of $\mathrm{P}^{\mathrm{BrA}}$ abolishes its local and systemic RNA silencing suppression, while deletion of 25 amino acid residues in the C-terminus (225-249 aa) still allows for suppression of local RNA silencing but not systemic RNA silencing [46]. In addition, studies show that deletion of $15 \mathrm{~N}$-terminal amino acid residues (2-15 aa) of SCYLV P0 abolishes both local and systemic RNA silencing suppression activity. In contrast, only systemic RNA silencing suppression was abolished when the 15 C-terminal amino acid residues were deleted [39]. In this study, we found that single amino acid deletion at position 2 or 3 in the N-terminus of $\mathrm{P}^{\mathrm{PM}}$ abolished its VSR activity, and deletion of 41 C-terminal amino acid residues (230-270 aa) did not have any effect. This could be explained by our prediction of the secondary structure of $\mathrm{P} 0{ }^{\mathrm{PM}}$, in which we found that the C-terminal domain did not form any structure. Taken together, these results indicate that N-terminal residues in the P0 proteins are essential for VSR activity, but C-terminal residues are not required for its local VSR activity; only those P0 with systemic VSR activity need its C-terminal residues. The reason for the difference in systemic RNA silencing suppression between these P0s and role of the C-terminal residues should be further investigated. Thus, obtaining and analyzing the crystal structure of $\mathrm{P} 0$ may provide more explanation as to how these amino acids affect the suppression of RNA silencing.

Multiple alignment of the $\mathrm{P} 0$ proteins from poleroviruses revealed that $\mathrm{P} 0^{\mathrm{PM}}$ had a similar F-box-like motif. Substitution of the conserved LPP residues in the F-box-like motif of $\mathrm{P}^{\mathrm{PM}}$ abolished suppressor activity, which was consistent with a previous publication [48]. Our results indicated that $\mathrm{P} 0^{\mathrm{PM}}$ also functioned as an F-box protein. In addition, we found that substitution of the C-terminal I225/W226 residues destroyed $\mathrm{P} 0^{\mathrm{PM}}$ suppressor activity. Early studies have shown that P0 proteins interact with SKP1 via its F-box-like motif $[35,46,49]$. Point mutations in the F-box-like motif of P0 not only abolish the silencing suppressor activity of P0 but also abolish the P0-SKP1 interaction [35]. Our $\mathrm{Y} 2 \mathrm{H}$ analysis revealed that $\mathrm{F}$-box protein $\mathrm{P}^{\mathrm{PM}}$ failed to interact with $\mathrm{NbSKP} 1$. Interestingly, we discovered that residue 66 of $\mathrm{P}^{\mathrm{PM}}$ at the $\mathrm{L} / \mathrm{I}$ position of F-box-like motif was an $\mathrm{F}$ instead of the consensus $\mathrm{L}$ or I residue, which may be the reason why $\mathrm{P}^{\mathrm{PM}}$ was unable to interact with $\mathrm{NbSKP} 1$. Additional methods for investigating $\mathrm{PO}^{\mathrm{PM}}-\mathrm{SKP} 1$ interaction should be performed in future studies. Studies have demonstrated that not all F-box P0 proteins interact with SKP1. For example, $\mathrm{P} 0^{\mathrm{PL}}$ also has a conserved F-box-like motif and suppresses RNA silencing but fails to interact with SKP1 [43]. In addition, a recent study of $\mathrm{BrYV} P 0$ showed that the $\mathrm{P} 0^{\mathrm{Br}}-\mathrm{SKP} 1$ interaction is not directly required for its suppression activity but instead is needed for protecting $\mathrm{P} 0^{\mathrm{Br}}$ from degradation through autophagy and proteasome pathways [46]. Our data further supported this finding that RNA silencing suppression activity of $\mathrm{P0}$ is independent of $\mathrm{P0}-\mathrm{SKP} 1$ interaction. However, it is likely that $\mathrm{PO}^{\mathrm{PL}}$ and $\mathrm{P0} 0^{\mathrm{PM}}$ may interact with SKP1 from natural hosts or other SKP1-like proteins from N. benthamiana that have same activity with SKP1.

Suppression of RNA silencing by P0 is associated with degradation of AGO1 protein [31,32]. We demonstrated that $\mathrm{P} 0{ }^{\mathrm{PM}}$ triggered AGO1 degradation and LP and I225R mutants did affect AGO1 accumulation, whereas LPP and IWRR had no effect on AGO1 accumulation and consequently were unable to suppress RNA silencing. Furthermore, we found that AGO1 degradation was correlated with $\mathrm{P}^{\mathrm{PM}}$ suppressor activity. Previous research has shown that $\mathrm{P0}^{\mathrm{Tu}}$ and $\mathrm{P}^{\mathrm{CA}}$ directly bind to AGO1, although others like WYDV-RMV2 P0 fail to interact with AGO1 [32,45]. Whether P0 ${ }^{\mathrm{PM}}$ directly interact with AGO1 and/or other proteins of the RNA silencing pathway to promote AGO1 degradation or indirectly influence AGO1 stability by targeting another protein capable of stabilizing AGO1 still needs to be elucidated in future studies. 


\section{Materials and Methods}

\subsection{Plant Material and Growth Conditions}

Wild-type Nicotiana benthamiana and green fluorescent protein (GFP) transgenic N. benthamiana $16 \mathrm{c}$ plants were grown at $24^{\circ} \mathrm{C}$ with a $16 \mathrm{~h}$ light/ $8 \mathrm{~h}$ dark cycle.

\subsection{Plasmid Constructs}

All of the primers are listed in Table 1.

Table 1. Primer sequences used for polymerase chain reaction.

\begin{tabular}{|c|c|}
\hline Primer & Sequence $\left(5^{\prime}-3^{\prime}\right)$ \\
\hline POXhoF & TATCTCGAGATGAACGTGTTAATC \\
\hline P0TGA-ApaR & TATGGGCCCTCATAGCTCCCAAAACCCTTCG \\
\hline P0ApaR & TATGGGCCCTAGCTCCCAAAACCCTTCG \\
\hline$\Delta 2 \mathrm{XhoF}$ & TATCTCGAGATGGTGTTAATCAATCAATACAC \\
\hline$\Delta 3 \mathrm{XhoF}$ & TATCTCGAGATGAACTTAATCAATCAAT \\
\hline$\Delta 229-270 \mathrm{TGAR}$ & CGGGATCCGGGCCCTCAAAGCTCCCAAATATCAGATG \\
\hline$\Delta 229-270-\mathrm{R}$ & TATGGGCCCAAGCTCCCAA ATATCAGATG \\
\hline Primer & $\begin{array}{l}\text { Sequence }\left(5^{\prime}-3^{\prime}\right) \\
\end{array}$ \\
\hline$\Delta 230-270 \mathrm{TGAR}$ & CGGGATCCGGGCCCTCAGAAAAGCTCCCAAATATCAG \\
\hline$\Delta 230-270-\mathrm{R}$ & TATGGGCCCGAAAAGCTCC CAAATATCAG \\
\hline LP-F & $\overline{\text { GCCGCTTTTCTATTCGGGGGCTTC }}$ \\
\hline LP-R & 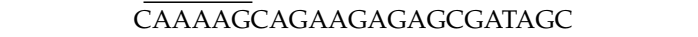 \\
\hline LPP-F & TTACACGGGAGTAACCG \\
\hline LPP-R & GCGGGCGATGACCAGTTG \\
\hline I225R-F & GATAGGTGGGAGCTTTTCGGT \\
\hline I225R-R & AGATGTAAGAGCTTTGCCGTAG \\
\hline W226R-F & GATATTAGGGAGCTTTTCGGT \\
\hline PONdeF & TATCATATGAACGTGTTAATC \\
\hline POBamHR & TATGGATCCTCATAGCTCCCAAAACCCTTCG \\
\hline
\end{tabular}

The vectors pGD and pGDG [53] were used for transient expression. For the VSR activity assay, $\mathrm{P}^{\mathrm{PM}}$ and its mutants with stop codon were cloned into pGD for the GFP agroinfiltration assay. In the AGO1 degradation experiment, $\mathrm{P} 0^{\mathrm{PM}}$ and corresponding $\mathrm{P} 0^{\mathrm{PM}}$ mutants without stop codon were cloned into pGD-3Flag, a modified version of vector pGD that has a C-terminal-fused $3 \times$ Flag tag.

For the $\mathrm{Y} 2 \mathrm{H}$ assay, the full length of $\mathrm{P} 0{ }^{\mathrm{PM}}$ was cloned into pGDBKT7 containing a binding domain (BD) to generate BD-P0 ${ }^{\mathrm{PM}}$. Construction of $\mathrm{pGDBKT7-P0}{ }^{\mathrm{BrA}}$ and $\mathrm{pGAD}-\mathrm{NbSKP} 1$ was described previously [46,57].

\subsection{Agrobacterium-Mediated Transient Expression and GFP Imaging}

Plasmids were transformed into the Agrobacterium tumefaciens strain EHA105 using the freeze-thaw method [58]. Co-infiltration assays were performed as previously described [59]. The recombinant EHA105 or C58CI was grown overnight; resuspended in infiltration buffer $(10 \mathrm{mM} \mathrm{MgCl}, 10 \mathrm{mM} \mathrm{MES}$, and $100 \mu \mathrm{M}$ acetosyringone); and incubated at room temperature for at least $3 \mathrm{~h}$ before infiltration. The A. tumefaciens cultures were infiltrated into N. benthamiana leaves, and then the infiltrated leaves were detached for the corresponding assays. Final dilutions of the cultures used in co-infiltration assays were 0.5 OD600 for each construct.

Leaves were illuminated under a BLAK-RAY non-UV semiconductor inspection lamp (B-100AP/R; UVP Inc., Upland, CA, USA), and images were taken with a digital camera (CoolPix 4500; Nikon, Tokyo, Japan) at 5 and 14 days post-infiltration (dpi). All experiments shown in the results were repeated at least three times.

\subsection{Yeast Two-Hybrid (Y2H) Assay}

For the Y2H assay, the Clontech Matchmaker GAL4 Two-Hybrid System 3 (Clontech, Mountain View, CA, USA) was used. BD, BD-P0 ${ }^{\mathrm{PM}}$, and BD-P0 ${ }^{\mathrm{BrA}}$ were transformed into the yeast host strain 
Y187. AD and AD-NbSKP1 were transformed into the yeast host strain AH109. Protein interactions were tested using the yeast mating assay. The mated transformants were plated onto synthetic dropout (SD) media lacking Trp and Leu (SD/-WL) and SD media lacking Ade, His, Trp, and Leu (SD/-AHLW). The plates were incubated at $30{ }^{\circ} \mathrm{C}$ for $3-5$ days.

\subsection{Protein Extraction and Western Blots}

Total proteins were extracted from infiltrated $N$. benthamiana leaves using $2 \times$ sodium dodecyl sulfate (SDS) sample buffer (100 mM Tris, $\mathrm{pH} 6.8 ; 4 \% w / v$ SDS; $20 \%$ v $v$ glycerol; and $0.2 \% w / v$ bromophenol blue). Proteins were separated with SDS polyacrylamide gel electrophoresis. Western blots were performed with the primary anti-Flag antibody (1:1,000; Sigma-Aldrich, St. Louis, MO, USA), anti-GFP antibody (1:3000), or anti-anti-c-myc antibody (1:1000; Sigma-Aldrich, St. Louis, MO, USA) and then incubated with anti-rabbit goat HRP secondary antibody (1:3000; Bio-Rad, Hercules, CA, USA). Finally, the membrane was detected with an enhanced chemiluminescence detection kit (GE Healthcare, Buckinghamshire, UK) according to the manufacturer's instructions.

Author Contributions: C.H., Q.S., and T.Z. (Tao Zhuo) designed the research; Q.S., T.Z. (Tao Zhuo), and T.Z. (Tianyu Zhao) performed the experiments; Q.S., C.Z., and C.H. analyzed the data; Q.S., C.H. wrote the paper; C.Z., Y.L., Y.W., D.L., and J.Y. contributed through discussions. All authors have read and agreed to the published version of the manuscript.

Funding: This study was partially supported by the National Natural Science Foundation of China (31901857 and 31671995) and startup funding (880419009) from Shenyang Agricultural University.

Acknowledgments: We thank David Baulcombe (Department of Plant Sciences, University of Cambridge, UK) for providing wild-type N. benthamiana and GFP transgenic N. benthamiana line 16c, Andrew O. Jackson (Department of Plant and Microbial Biology, University of California, Berkeley, USA) for providing vectors pGD, pGDG and pGDP19 ${ }^{\text {TBSV }}$, and Huishan Guo (Institute of Microbiology, Chinese Academy of Sciences, China) for providing plasmid pCAMBIA-35S-6myc-AGO1.

Conflicts of Interest: The authors declare no conflict of interest. The funders had no role in the design of the study; in the collection, analyses, or interpretation of data; in the writing of the manuscript; or in the decision to publish the results.

\section{Abbreviations}

$\begin{array}{ll}\text { AGO } & \text { ARGONAUTE } \\ \text { BMYV } & \text { Beet mild yellowing virus } \\ \text { BrYV } & \text { Brassica yellows virus } \\ \text { CABYV } & \text { Cucurbit aphid-borne yellows virus } \\ \text { CLRDV } & \text { Cotton leafroll dwarf virus } \\ \text { CYDV } & \text { Cereal yellow dwarf virus } \\ \text { MABYV } & \text { Melon aphid-borne yellow virus } \\ \text { MaYMV } & \text { Maize yellow mosaic virus } \\ \text { MYDV } & \text { Maize yellow dwarf virus } \\ \text { PMCV } & \text { Pea mild chlorosis virus } \\ \text { PLRV } & \text { Potato leafroll virus } \\ \text { ScYLV } & \text { Sugarcane yellow leaf virus } \\ \text { TBSV } & \text { Tomato bushy stunt virus } \\ \text { VSRs } & \text { Viral suppressors of RNA silencing }\end{array}$

\section{References}

1. Blevins, T.; Rajeswaran, R.; Shivaprasad, P.V.; Beknazariants, D.; Si-Ammour, A.; Park, H.S.; Vazquez, F.; Robertson, D.; Meins, F.; Hohn, T.; et al. Four plant Dicers mediate viral small RNA biogenesis and DNA virus induced silencing. Nucleic Acids Res. 2006, 34, 6233-6246. [CrossRef]

2. Deleris, A.; Gallego-Bartolome, J.; Bao, J.; Kasschau, K.D.; Carrington, J.C.; Voinnet, O. Hierarchical action and inhibition of plant dicer-like proteins in antiviral defense. Science 2006, 313, 68-71. [CrossRef] [PubMed] 
3. Zhang, X.; Niu, D.; Carbonell, A.; Wang, A.; Lee, A.; Tun, V.; Wang, Z.; Carrington, J.C.; Chang, C.E.A.; Jin, H. ARGONAUTE PIWI domain and microRNA duplex structure regulate small RNA sorting in Arabidopsis. Nat. Commun. 2014, 5, 5468. [CrossRef] [PubMed]

4. Dzianott, A.; Sztuba-Solinska, J.; Bujarski, J.J. Mutations in the antiviral RNAi defense pathway modify Brome mosaic virus RNA recombinant profiles. Mol. Plant. Microbe Interact. 2012, 25, 97-106. [CrossRef] [PubMed]

5. García-Ruíz, H.; Carbonell, A.; Hoyer, J.S.; Fahlgren, N.; Gilbert, K.B.; Takeda, A.; Giampetruzzi, A.; Ruiz, M.T.G.; McGinn, M.G.; Lowery, N.V.; et al. Roles and programming of arabidopsis ARGONAUTE proteins during turnip mosaic virus infection. PLoS Pathog. 2015, 11, e1004755. [CrossRef]

6. Carbonell, A.; Fahlgren, N.; Garcia-Ruiz, H.; Gilbert, K.B.; Montgomery, T.A.; Nguyen, T.; Cuperus, J.T.; Carrington, J.C. Functional analysis of three arabidopsis ARGONAUTES using slicer-defective mutants. Plant. Cell 2012, 24, 3613-3629. [CrossRef]

7. Ghoshal, B.; Sanfaçon, H. Temperature-dependent symptom recovery in Nicotiana benthamiana plants infected with tomato ringspot virus is associated with reduced translation of viral RNA2 and requires ARGONAUTE 1. Virology 2014, 456, 188-197. [CrossRef]

8. Mourrain, P.; Béclin, C.; Elmayan, T.; Feuerbach, F.; Godon, C.; Morel, J.B.; Jouette, D.; Lacombe, A.M.; Nikic, S.; Picault, N.; et al. Arabidopsis SGS2 and SGS3 genes are required for posttranscriptional gene silencing and natural virus resistance. Cell 2000, 101, 533-542. [CrossRef]

9. Vazquez, F.; Vaucheret, H.; Rajagopalan, R.; Lepers, C.; Gasciolli, V.; Mallory, A.C.; Hilbert, J.L.; Bartel, D.P.; Crété, P. Endogenous trans-acting siRNAs regulate the accumulation of arabidopsis mRNAs. Mol. Cell 2004, 16, 69-79. [CrossRef]

10. Schwach, F.; Vaistij, F.E.; Jones, L.; Baulcombe, D.C. An RNA-dependent RNA polymerase prevents meristem invasion by potato virus $X$ and is required for the activity but not the production of a systemic silencing signal. Plant. Physiol. 2005, 138, 1842-1852. [CrossRef]

11. Wang, X.B.; Jovel, J.; Udomporn, P.; Wang, Y.; Wu, Q.; Li, W.X.; Gasciolli, V.; Vaucheret, H.; Ding, S.W. The 21-nucleotide, but not 22-nucleotide, viral secondary small interfering RNAs direct potent antiviral defense by two cooperative argonautes in arabidopsis thaliana. Plant. Cell 2011, 23, 1625-1638. [CrossRef]

12. Diaz-Pendon, J.A.; Li, F.; Li, W.X.; Ding, S.W. Suppression of antiviral silencing by cucumber mosaic virus $2 \mathrm{~b}$ protein in arabidopsis is associated with drastically reduced accumulation of three classes of viral small interfering RNAs. Plant. Cell 2007, 19, 2053-2063. [CrossRef]

13. Donaire, L.; Barajas, D.; Martínez, B.; Martínez-Priego, L.; Pagán, I.; Llave, C. Structural and genetic requirements for the biogenesis of tobacco rattle virus-derived small interfering RNAs. J. Virol. 2008, 82, 5167-5177. [CrossRef] [PubMed]

14. Garcia-Ruiz, H.; Takeda, A.; Chapman, E.J.; Sullivan, C.M.; Fahlgren, N.; Brempelis, K.J.; Carrington, J.C. Arabidopsis RNA-dependent RNA polymerases and dicer-like proteins in antiviral defense and small interfering RNA biogenesis during turnip mosaic virus infection. Plant. Cell 2010, 22, 481-496. [CrossRef] [PubMed]

15. Wu, Q.; Wang, X.; Ding, S.W. Viral suppressors of RNA-based viral immunity: Host targets. Cell Host Microbe 2010, 8, 12-15. [CrossRef] [PubMed]

16. Diaz-Pendon, J.A.; Ding, S.W. Direct and indirect roles of viral suppressors of RNA silencing in pathogenesis. Annu. Rev. Phytopathol. 2008, 46, 303-326. [CrossRef] [PubMed]

17. Burgyán, J.; Havelda, Z. Viral suppressors of RNA silencing. Trends Plant. Sci. 2011, 16, 265-272. [CrossRef]

18. Incarbone, M.; Dunoyer, P. RNA silencing and its suppression: Novel insights from in planta analyses. Trends Plant. Sci. 2013, 18, 382-392. [CrossRef]

19. Pumplin, N.; Voinnet, O. RNA silencing suppression by plant pathogens: Defence, counter-defence and counter-counter-defence. Nat. Rev. Genet. 2013, 11, 745-760. [CrossRef]

20. Goto, K.; Kobori, T.; Kosaka, Y.; Natsuaki, T.; Masuta, C. Characterization of silencing suppressor $2 \mathrm{~b}$ of cucumber mosaic virus based on examination of its small RNA-binding abilities. Plant. Cell Physiol. 2007, 48, 1050-1060. [CrossRef]

21. Merai, Z.; Kerényi, Z.; Kertész, S.; Magna, M.; Lakatos, L.; Silhavy, D. Double-stranded RNA binding may be a general plant RNA viral strategy to suppress RNA silencing. J. Virol. 2006, 80, 5747-5756. [CrossRef] [PubMed]

22. Vargason, J.M.; Szittya, G.; Burgyán, J.; Hall, T.M.T. Size selective recognition of siRNA by an RNA silencing suppressor. Cell 2003, 115, 799-811. [CrossRef]

23. Ye, K.; Malinina, L.; Patel, D.J. Recognition of small interfering RNA by a viral suppressor of RNA silencing. Nature 2003, 426, 874-878. [CrossRef] [PubMed] 
24. Silhavy, D.; Molnár, A.; Lucioli, A.; Szittya, G.; Hornyik, C.; Tavazza, M.; Burgyán, J. A viral protein suppresses RNA silencing and binds silencing-generated, 21- to 25-nucleotide double-stranded RNAs. EMBO J. 2002, 21, 3070-3080. [CrossRef] [PubMed]

25. Glick, E.; Zrachya, A.; Levy, Y.; Mett, A.; Gidoni, D.; Belausov, E.; Citovsky, V.; Gafni, Y. Interaction with host SGS3 is required for suppression of RNA silencing by tomato yellow leaf curl virus V2 protein. Proc. Natl. Acad. Sci. USA 2007, 105, 157-161. [CrossRef] [PubMed]

26. Haas, G.; Azevedo, J.; Moissiard, G.; Geldreich, A.; Himber, C.; Bureau, M.; Fukuhara, T.; Keller, M.; Voinnet, O. Nuclear import of CaMV P6 is required for infection and suppression of the RNA silencing factor DRB4. EMBO J. 2008, 27, 2102-2112. [CrossRef]

27. Zhang, X.; Yuan, Y.R.; Pei, Y.; Lin, S.S.; Tuschl, T.; Patel, D.J.; Chua, N.H. Cucumber mosaic virus-encoded 2b suppressor inhibits Arabidopsis Argonaute1 cleavage activity to counter plant defense. Genes Dev. 2006, 20, 3255-3268. [CrossRef]

28. Azevedo, J.; Garcia, D.; Pontier, D.; Ohnesorge, S.; Yu, A.; Garcia, S.; Braun, L.; Bergdoll, M.; Hakimi, M.A.; Lagrange, T.; et al. Argonaute quenching and global changes in Dicer homeostasis caused by a pathogen-encoded GW repeat protein. Genes Dev. 2010, 24, 904-915. [CrossRef]

29. Chiu, M.H.; Chen, I.H.; Baulcombe, D.C.; Tsai, C.H. The silencing suppressor P25 of Potato virus X interacts with Argonaute1 and mediates its degradation through the proteasome pathway. Mol. Plant. Pathol. 2010, 11, 641-649. [CrossRef]

30. Karran, R.A.; Sanfaçon, H. Tomato ringspot virus coat protein binds to ARGONAUTE 1 and suppresses the translation repression of a reporter gene. Mol. Plant. Microbe Interact. 2014, 27, 933-943. [CrossRef]

31. Baumberger, N.; Tsai, C.H.; Lie, M.; Havecker, E.; Baulcombe, D.C. The polerovirus silencing suppressor P0 targets ARGONAUTE proteins for degradation. Curr. Biol. 2007, 17, 1609-1614. [CrossRef] [PubMed]

32. Bortolamiol, D.; Pazhouhandeh, M.; Marrocco, K.; Genschik, P.; Ziegler-Graff, V. The polerovirus F box protein P0 targets ARGONAUTE1 to suppress RNA silencing. Curr. Biol. 2007, 17, 1615-1621. [CrossRef] [PubMed]

33. Csorba, T.; Lózsa, R.; Hutvágner, G.; Burgyán, J. Polerovirus protein P0 prevents the assembly of small RNA-containing RISC complexes and leads to degradation of ARGONAUTE1. Plant. J. 2010, 62, 463-472. [CrossRef] [PubMed]

34. Derrien, B.; Baumberger, N.; Schepetilnikov, M.; Viotti, C.; De Cillia, J.; Ziegler-Graff, V.; Isono, E.; Schumacher, K.; Genschik, P. Degradation of the antiviral component ARGONAUTE1 by the autophagy pathway. Proc. Natl. Acad. Sci. USA 2012, 109, 15942-15946. [CrossRef] [PubMed]

35. Pazhouhandeh, M.; Dieterle, M.; Marrocco, K.; Lechner, E.; Berry, B.; Brault, V.; Hemmer, O.; Kretsch, T.; Richards, K.E.; Genschik, P.; et al. F-box-like domain in the polerovirus protein P0 is required for silencing suppressor function. Proc. Natl. Acad. Sci. USA 2006, 103, 1994-1999. [CrossRef]

36. Pfeffer, S.; Dunoyer, P.; Heim, F.; Richards, K.E.; Jonard, G.; Ziegler-Graff, V. P0 of beet western yellows virus is a suppressor of posttranscriptional gene silencing. J. Virol. 2002, 76, 6815-6824. [CrossRef]

37. Taliansky, M.; Mayo, M.A.; Barker, H. Potato leafroll virus: A classic pathogen shows some new tricks. Mol. Plant. Pathol. 2003, 4, 81-89. [CrossRef]

38. Stevens, M.; Freeman, B.; Liu, H.Y.; Herrbach, E.; Lemaire, O. Beet poleroviruses: Close friends or distant relatives? Mol. Plant. Pathol. 2005, 6, 1-9. [CrossRef]

39. Mangwende, T.; Wang, M.L.; Borth, W.; Hu, J.; Moore, P.H.; Mirkov, T.E.; Albert, H.H. The P0 gene of Sugarcane yellow leaf virus encodes an RNA silencing suppressor with unique activities. Virology 2009, 384, 38-50. [CrossRef]

40. Han, Y.H.; Xiang, H.Y.; Wang, Q.; Li, Y.Y.; Wu, W.Q.; Han, C.G.; Li, D.; Yu, J. Ring structure amino acids affect the suppressor activity of melon aphid-borne yellows virus P0 protein. Virology 2010, 406, 21-27. [CrossRef]

41. Kozlowska-Makulska, A.; Guilley, H.; Szyndel, M.S.; Beuve, M.; Lemaire, O.; Herrbach, E.; Bouzoubaa, S. P0 proteins of European beet-infecting poleroviruses display variable RNA silencing suppression activity. J. Gen. Virol. 2009, 91, 1082-1091. [CrossRef]

42. Delfosse, V.C.; Agrofoglio, Y.; Casse, M.F.; Kresic, I.B.; Hopp, H.E.; Ziegler-Graff, V.; Distéfano, A.J. The P0 protein encoded by cotton leafroll dwarf virus (CLRDV) inhibits local but not systemic RNA silencing. Virus Res. 2014, 180, 70-75. [CrossRef] 
43. Zhuo, T.; Li, Y.Y.; Xiang, H.Y.; Wu, Z.Y.; Wang, X.B.; Wang, Y.; Zhang, Y.; Li, D.; Yu, J.L.; Han, C.G. Amino acid sequence motifs essential for P0-mediated suppression of RNA silencing in an isolate of potato leafroll virus from inner mongolia. Mol. Plant. Microbe Interact. 2014, 27, 515-527. [CrossRef] [PubMed]

44. Chen, S.; Jiang, G.; Wu, J.; Liu, Y.; Qian, Y.; Zhou, X. Characterization of a novel polerovirus infecting maize in China. Viruses 2016, 8, 120. [CrossRef] [PubMed]

45. Wang, F.; Zhao, X.; Dong, Q.; Zhou, B.; Gao, Z. Characterization of an RNA silencing suppressor encoded by maize yellow dwarf virus-RMV2. Virus Genes 2018, 54, 570-577. [CrossRef] [PubMed]

46. Li, Y.Y.; Sun, Q.; Zhao, T.; Xiang, H.; Zhang, X.; Wu, Z.; Zhou, C.; Zhang, X.; Wang, Y.; Zhang, Y.; et al. Interaction between Brassica yellows virus silencing suppressor P0 and plant SKP1 facilitates stability of P0 in vivo against degradation by proteasome and autophagy pathways. New Phytol. 2019, 222, 1458-1473. [CrossRef] [PubMed]

47. Liu, Y.; Zhai, H.; Zhao, K.; Wu, B.; Wang, X. Two suppressors of RNA silencing encoded by cereal-infecting members of the family Luteoviridae. J. Gen. Virol. 2012, 93, 1825-1830. [CrossRef] [PubMed]

48. Fusaro, A.F.; Corrêa, R.L.; Nakasugi, K.; Jackson, C.; Kawchuk, L.M.; Vaslin, M.F.; Waterhouse, P.M. The Enamovirus P0 protein is a silencing suppressor which inhibits local and systemic RNA silencing through AGO1 degradation. Virology 2012, 426, 178-187. [CrossRef]

49. Almasi, R.; Miller, W.A.; Ziegler-Graff, V.; Vachon, V.K.; Conn, G.L. Mild and severe cereal yellow dwarf viruses differ in silencing suppressor efficiency of the P0 protein. Virus Res. 2015, 208, 199-206. [CrossRef] [PubMed]

50. Zhou, C.J.; Xiang, H.Y.; Zhuo, T.; Li, D.; Yu, J.L.; Han, C.G. Nucleotide sequence of a chickpea chlorotic stunt virus relative that infects pea and faba bean in China. Arch. Virol. 2012, 157, 1393-1396. [CrossRef]

51. Johansen, L.K. Silencing on the spot. Induction and suppression of RNA silencing in the agrobacterium-mediated transient expression system. Plant. Physiol. 2001, 126, 930-938. [CrossRef] [PubMed]

52. Ruiz, M.T.; Voinnet, O.; Baulcombe, D.C. Initiation and maintenance of virus-induced gene silencing. Plant Cell 1998, 10, 937-946. [CrossRef] [PubMed]

53. Goodin, M.; Dietzgen, R.G.; Schichnes, D.; Ruzin, S.; Jackson, A.O. pGD vectors: Versatile tools for the expression of green and red fluorescent protein fusions in agroinfiltrated plant leaves. Plant. J. 2002, 31, 375-383. [CrossRef] [PubMed]

54. Voinnet, O.; Rivas, S.; Mestre, P.; Baulcombe, D. An enhanced transient expression system in plants based on suppression of gene silencing by the p19 protein of tomato bushy stunt virus. Plant. J. 2003, 33, 949-956. [CrossRef] [PubMed]

55. Rashid, M.; Zhang, X.Y.; Wang, Y.; Li, D.; Yu, J.L.; Han, C.G. The three essential motifs in P0 for suppression of RNA silencing activity of potato leafroll virus are required for virus systemic infection. Viruses 2019, 11, 170. [CrossRef]

56. Wang, K.D.; Empleo, R.; Nguyen, T.T.V.; Moffett, P.; Sacco, M.A. Elicitation of hypersensitive responses in Nicotiana glutinosa by the suppressor of RNA silencing protein P0 from poleroviruses. Mol. Plant Pathol. 2015, 16, 435-448. [CrossRef]

57. Wang, Q.; Tao, T.; Han, Y.H.; Chen, X.R.; Fan, Z.; Li, D.; Yu, J.L.; Han, C.G. Nonstructural protein P7-2 encoded by Rice black-streaked dwarf virus interacts with SKP1, a core subunit of SCF ubiquitin ligase. Virol. J. 2013, 10, 325. [CrossRef]

58. Holsters, M.; De Waele, D.; Depicker, A.; Messens, E.; Van Montagu, M.; Schell, J. Transfection and transformation of Agrobacterium tumefaciens. Mol. Gen. Genet. 1978, 163, 181-187. [CrossRef]

59. Sun, Q.; Li, Y.Y.; Wang, Y.; Zhao, H.H.; Zhao, T.Y.; Zhang, Z.Y.; Li, D.; Yu, J.L.; Wang, X.; Zhang, Y.L.; et al. Brassica yellows virus P0 protein impairs the antiviral activity of NbRAF2 in Nicotiana benthamiana. J. Exp. Bot. 2018, 69, 3127-3139. [CrossRef]

(C) 2020 by the authors. Licensee MDPI, Basel, Switzerland. This article is an open access article distributed under the terms and conditions of the Creative Commons Attribution (CC BY) license (http://creativecommons.org/licenses/by/4.0/). 